\title{
First record of Heptranchias perlo (Bonnaterre 1788) in Guatemala's Caribbean Sea
}

\author{
Ana Hacohen-Domené ${ }^{* *}$ (D, Francisco Polanco-Vásquez ${ }^{1}$ and Rachel T. Graham²
}

\begin{abstract}
Background: This report represents the first record of the sharpnose sevengill shark Heptranchias perlo in Guatemala's Caribbean Sea.

Methods: Two H. perlo specimens were captured by artisanal fishermen of the coastal community, El Quetzalito. All specimens were captured with a trammel net, in waters of $200 \mathrm{~m}$ depth

Results: Both specimens were female with total lengths of 280 and $370 \mathrm{~mm}$. Details regarding the identification and measurement of both specimens are presented.

Conclusion: These specimens represent the first record of both species in Guatemalan waters. Also, this report further increases the species' range of distribution in the Caribbean and Central America.
\end{abstract}

Keywords: First record, Deep-water sharks, Hexanchidae, Caribbean

\section{Background}

The family Hexanchidae includes three genera and four described species: Hexanchus Rafinesque 1810, Heptranchias Rafinesque 1810, and Notorynchus Ayres 1855 (Ebert and Stehmann 2013). Hexanchidae sharks have a worldwide distribution in cold temperate to tropical seas. Most species in the family are deepwater inhabitants of the outer continental shelves, upper continental slopes, insular shelves and slopes, and submarine canyons down to at least $2500 \mathrm{~m}$ depth, occurring in both benthic and neritic (Carpenter 2002; Ebert and Stehmann 2013).

The sharpnose sevengill shark, Heptranchias perlo (Bonnattere1788), is uncommon through its range and many aspects of its biology are poorly known. H. perlo has been known to occur primarily in deep waters down to $1000 \mathrm{~m}$ (Compagno et al. 2005; Ebert et al. 2013).

The sharpnose sevengill shark occurrence in the Western Atlantic has been reported in Mexico, Jamaica, Bahamas (USA), Cuba and Panama (Bonfil 1997; Claro and Parenti 2001; Paul and Fowler 2003; McLaughlin and Morrissey

\footnotetext{
* Correspondence: ahacohen@fundacionmundoazul.com

${ }^{1}$ Fundación Mundo Azul, Blvd. Rafael Landívar 10-05 Paseo Cayalá Zona 16,

Edificio D1 Oficina 212, Guatemala City, Guatemala

Full list of author information is available at the end of the article
}

2004; Kyne et al. 2012; Benavides et al. 2014). The importance of this study lies in the fact that it represents the first confirmed record of occurrence of $H$. perlo in Guatemala's Caribbean Sea. Currently, H. perlo is listed as "Near Threatened" by the International Union for the Conservation of Nature's Red List (Paul and Fowler 2003).

\section{Methods}

On the 20th March 2016, two female sevengill sharks were captured by artisanal fishermen in Guatemala's Caribbean Sea and landed in the coastal village of El Quetzalito, Izabal (15 $\left.49.776 \mathrm{~N},-88^{\circ} 12.340 \mathrm{~W}\right)$ (Fig. 1). All specimens were captured with a $1000 \mathrm{~m}$ long bottom trammel net of 3.5 inches mesh size and one panel. Specimens were captured at approximately $200 \mathrm{~m}$ depth, based on known length of net deployed. All specimens were examined and identified to species level using identification guides (Compagno 1984; Compagno et al. 2001).

Both specimens were preserved in formaldehyde $(10 \%)$ and subsequently transferred to ethyl alcohol (70\%) for final preservation. Both sevengill shark specimens were deposited in the Laboratory of Biological Science and Oceanography, Centro de Estudios del Mar y Acuicultura (CEMA) of the Universidad San Carlos de Guatemala 


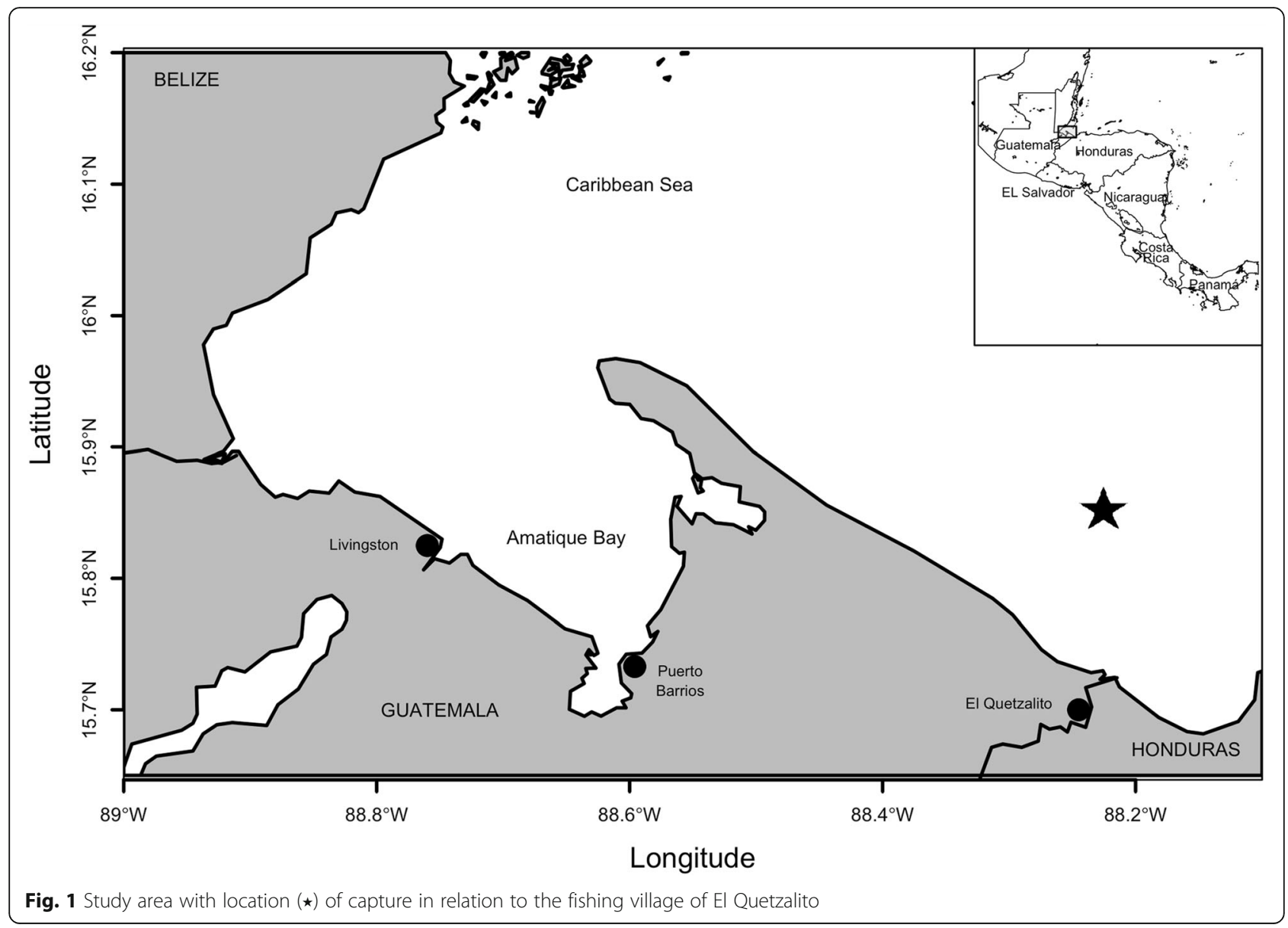

(USAC). The specimens are part of the collection registered to the Consejo Nacional de Áreas Protegidas (CONAP) under the reference number (Rf) 250 and 251. Measurements were taken on the sevengill shark specimens using a vernier calipers or measuring tape, as proposed by Compagno (2001). A total of 80 morphometric measurements were taken (Compagno 2001).

\section{Results}

Systematic account

Family: Hexanchidae

Genus: Heptranchias Rafinesque, 1810

Heptranchias perlo (Bonnaterre, 1788)

Common name: Sharpnose sevengill shark, cañabota (local name)

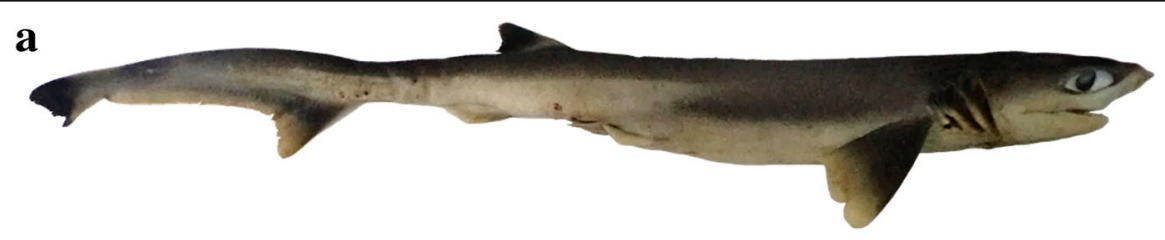

b

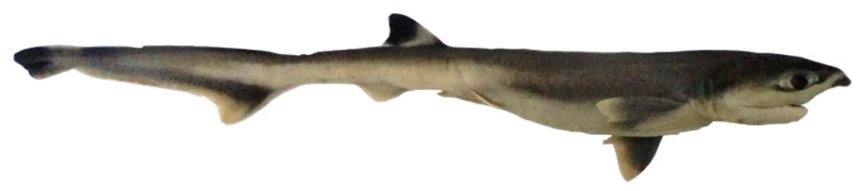

$10 \mathrm{~cm}$

Fig. 2 Heptranchias perlo: a. Rf250, female, $370 \mathrm{~mm}$ TL and (b). Rf251, female, $280 \mathrm{~mm}$ TL 
Table 1 Morphometric measurements $(\mathrm{mm}$ ) of individuals of two female specimens of Heptranchias perlo

\begin{tabular}{|c|c|c|}
\hline Measurements & $\operatorname{Rf} 250$ & $\operatorname{Rf} 251$ \\
\hline Total length & 370 & 280 \\
\hline Fork length & 280 & 210 \\
\hline Precaudal fin length & 260 & 190 \\
\hline Pre-first dorsal-fin length & 179.6 & 136.2 \\
\hline Head length & 80.5 & 62.9 \\
\hline Prebranchial length & 62.6 & 51.6 \\
\hline Prespiracular length & 55.4 & 44.1 \\
\hline Preorbital length & 21.9 & 18.5 \\
\hline Prepectoral-fin length & 73.3 & 59.1 \\
\hline Prepelvic-fin length & 157.1 & 166.7 \\
\hline Snout-vent length & 171.1 & 123 \\
\hline Preanal-fin length & 199.7 & 143.1 \\
\hline Dorsal caudal-fin space & 45.9 & 37 \\
\hline Pectoral-fin pelvic-fin space & 60.3 & 35 \\
\hline Pelvic-fin anal-fin space & 25.2 & 16 \\
\hline Anal-fin caudal-fin space & 34.4 & 25.3 \\
\hline Pelvic-fin caudal-fin space & 72.9 & 56.2 \\
\hline Vent caudal-fin length & 149.5 & 127.5 \\
\hline Prenarial length & 10.8 & 6.5 \\
\hline Preoral length & 19.4 & 16.5 \\
\hline Eye length & 20.2 & 14.7 \\
\hline Eye height & 7 & 4.1 \\
\hline Intergill length & 22.3 & 10.3 \\
\hline First gill slit height & 25.5 & 16.6 \\
\hline Second gill slit height & 21.6 & 13.1 \\
\hline Third gill slit height & 18.8 & 10.8 \\
\hline Fourth gill slit height & 16.9 & 9.1 \\
\hline Fifth gill slit height & 15.4 & 8.9 \\
\hline Sixth gill slit height & 14.4 & 7.3 \\
\hline Seventh gill slit height & 13 & 6.4 \\
\hline First dorsal-fin length & 30.5 & 21.1 \\
\hline First dorsal-fin anterior margin & 29.1 & 22.9 \\
\hline First dorsal-fin base & 23.5 & 16.3 \\
\hline First dorsal-fin height & 16.7 & 10.8 \\
\hline First dorsal-fin inner margin & 7 & 5.4 \\
\hline First dorsal-fin posterior margin & 15.2 & 12.8 \\
\hline Pectoral-fin anterior margin & 44.6 & 32.2 \\
\hline Pectoral-fin base & 38.2 & 26.2 \\
\hline Pectoral-fin inner margin & 22.2 & 12.6 \\
\hline Pectoral-fin posterior margin & 32.8 & 22.4 \\
\hline Pectoral-fin height & 35.9 & 24.3 \\
\hline Dorsal caudal-fin margin & 112.8 & 92.5 \\
\hline Preventral caudal-fin margin & 28.6 & 21.8 \\
\hline
\end{tabular}

Table 1 Morphometric measurements $(\mathrm{mm})$ of individuals of two female specimens of Heptranchias perlo (Continued)

\begin{tabular}{|c|c|c|}
\hline Upper postventral caudal-fin margin & 57.1 & 42.9 \\
\hline Lower postventral caudal-fin margin & 16.8 & 8.2 \\
\hline Caudal-fin fork width & 20.3 & 19.1 \\
\hline Caudal-fin fork length & 27.5 & 24.1 \\
\hline Subterminal caudal-fin margin & 16.5 & 13 \\
\hline Subterminal caudal-fin width & 8.2 & 4.2 \\
\hline Terminal caudal-fin margin & 12.4 & 11 \\
\hline Terminal caudal-fin lobe & 17.5 & 12.3 \\
\hline Pelvic-fin length & 34.9 & 27.1 \\
\hline Pelvic-fin anterior margin & 15.4 & 10.6 \\
\hline Pelvic-fin base & 20.6 & 14.5 \\
\hline Pelvic-fin height & 9.8 & 9.5 \\
\hline Pelvic-fin inner margin [length] & 12.3 & 10.5 \\
\hline Pelvic-fin posterior margin [length] & 24.6 & 16.9 \\
\hline Anal-fin length & 26.7 & 18.4 \\
\hline Anal-fin anterior margin & 15.4 & 10.7 \\
\hline Anal-fin base & 20.2 & 13.6 \\
\hline Anal-fin height & 9.9 & 7.6 \\
\hline Anal-fin inner margin & 6.3 & 4.7 \\
\hline Anal-fin posterior margin & 15.4 & 12.6 \\
\hline Head height & 28.7 & 20.5 \\
\hline Trunk height & 20.7 & 12.9 \\
\hline Abdomen height & 20.8 & 11.8 \\
\hline Tail height & 17.8 & 10.8 \\
\hline Caudal-fin peduncle height & 14.2 & 9.3 \\
\hline Mouth length & 36.9 & 28.4 \\
\hline Mouth width & 22.7 & 17.4 \\
\hline Nostril width & 5.7 & 3.5 \\
\hline Internarial space & 11 & 6.4 \\
\hline Interorbital space & 20 & 14.9 \\
\hline Spiracle length & 1.9 & 0.9 \\
\hline Eye spiracle space & 12.5 & 9.4 \\
\hline Head width & 29.7 & 19.7 \\
\hline Trunk width & 24.9 & 18.1 \\
\hline Abdomen width & 9.6 & 8.3 \\
\hline Tail width & 14.5 & 10.7 \\
\hline Caudal-fin peduncle width & 6.1 & 4.8 \\
\hline
\end{tabular}

\section{Material examined}

Rf 250: female, $370 \mathrm{~mm}$ TL (Fig. 2a, Table 1); Rf 251: female, $280 \mathrm{~mm}$ TL (Fig. 2b, Table 1).

\section{Description}

Small shark with seven pairs of gill openings. Slender body. Head extremely narrow and pointed, with large eyes 
and narrow mouth. Dorsal coloration brownish grey, with lighter coloration below. One spineless dorsal fin with black apex.

\section{Discussion}

This report represents the first record of $H$. perlo, in Guatemala's Caribbean Sea. In the Caribbean of Central America, $H$. perlo has only been reported for Panama (Benavides et al. 2014). During a deep water fishery survey using bottom trawling along the Caribbean coast of Central America, three $H$. perlo individuals were captured in Panama (Benavides et al. 2014); one female $(670 \mathrm{~mm}$ $\mathrm{TL}$ ) and two male (750-820 $\mathrm{mm} \mathrm{TL}$ ), sizes greater than the specimens reported in this study. Additionally, the capture depth of $H$. perlo, approx. 200 m (this study), coincides with the range describe by the species (Ebert and Stehmann 2013; Benavides et al. 2014). Knowledge of $H$. perlo biology is limited. A reproductive study conducted in the southwestern waters of Kyushu, Japan report H. perlo maturity of female is reached between $950 \mathrm{~mm}$ and $1050 \mathrm{~mm}$ (Tanaka and Mizue 1977). Moreover, birth size of $H$. perlo is $260-270 \mathrm{~mm}$ (Tanaka and Mizue 1977), close to that obtained in this study for Rf 251 specimen (280 mm TL).

Globally, this species is of minor commercial importance and occurs mostly as bycatch in bottom trawl and longline fisheries which may have caused population declines where deepwater fisheries have been practiced in the last decade. According to artisanal fishers in the region, $H$. perlo is rarely captured by the area's local fishermen, and is only captured incidentally when fishing with trammel nets. When captured, fishers rarely utilize the meat due to the species' small size although they render the liver for shark oil.

\section{Conclusion}

To date, reports regarding shark diversity of Guatemala's Caribbean Sea are scare (Thorson et al. 1966; HacohenDomené et al. 2016; Polanco-Vásquez et al. 2017). This study forms the first confirmed records of $H$. perlo in Guatemala's Caribbean Sea and increase the number of known shark species in Guatemala. This report further increases the species' range of distribution throughout the Caribbean and Central America. This study highlights the need for comprehensive deep-sea research surveys to obtain a more complete assessment of the region's deep-water elasmobranchs.

\section{Abbreviations \\ Cm: Centimeter; M: Meter; Mm: Millimeter; TL: Total length}

\section{Acknowledgements}

Fundación Mundo Azul would like to thank the community of El Quetzalito for their constant support to the research program in the area. Also, we would like to thank the Centro de Estudios del Mar y Acuicultura (CEMA) of the Universidad San Carlos de Guatemala (USAC) for providing the space to take the morphometric measurements.

\section{Funding}

Fundación Mundo Azul provided funding for the elasmobranch monitoring project in 2016. The Whitley Fund for Nature provided funding for RTG's time.

\section{Availability of data and materials}

The specimens are available at the Laboratory of Biological Science and Oceanography, Centro de Estudios del Mar y Acuicultura (CEMA) of the Universidad San Carlos de Guatemala (USAC). The specimens are part of the collection registered to the Consejo Nacional de Areas Protegidas (CONAP) under the reference numbers (Rf) 250 and (Rf) 251. Additionally, photographs and dataset supporting the conclusions of this article are included.

\section{Authors' contributions}

$\mathrm{AH}$ and FP participated in the identification of the species, recorded the morphometric data of all specimens, and contributed to draft the manuscript. RTG contributed to draft the manuscript. All authors read and approved the final manuscript.

\section{Competing interest}

The authors declare that they have no competing interests.

Consent for publication

Not applicable.

\section{Ethics approval}

The work was carried out under permit N00263-B, issued by the Consejo Nacional de Áreas Protegidas (CONAP), Guatemala.

\section{Publisher's Note}

Springer Nature remains neutral with regard to jurisdictional claims in published maps and institutional affiliations.

\section{Author details}

${ }^{1}$ Fundación Mundo Azul, Blvd. Rafael Landívar 10-05 Paseo Cayalá Zona 16, Edificio D1 Oficina 212, Guatemala City, Guatemala. 'MarAlliance, 32 Coconut Drive, PO Box 283, San Pedro, Belize.

Received: 7 February 2017 Accepted: 3 May 2017

Published online: 08 May 2017

\section{References}

Benavides R, Brenes CL, Márquez A. Análisis de la población de condrictios (Vertebrata: Chondrichthyes) de aguas demersales y profundas del Caribe centroamericano, a partir de faenas de prospección pesquera con redes de arrastre. Rev Cienc Mar Cost. 2014;6:9-27.

Bonfil R. Status of shark resources in the Southern Gulf of Mexico and Caribbean: implications for management. Fish Res. 1997;29(2):101-17.

Carpenter KE. The living marine resources of the Western Central Atlantic (Vol. 3). Rome: FAO; 2002.

Claro R, Parenti LR. The marine ichthyofauna of Cuba. Ecology of the marine fishes of Cuba, 21-57. In: Claro R, Lindeman KC, Parenti LR, editors. Ecology of marine fishes of Cuba. Washington and London: Smithsonian Institution Press; 2001.

Compagno LJV. FAO species catalogue. Vol. 4. Sharks of the world. An annotated and illustrated catalogue of shark species known to date. Part 1. Hexanchiforms to Lamniformes. Rome, Italy: FAO Fisheries Synopsis; 1984;4:1-249.

Compagno LJV. Sharks of the world. An annotated and illustrated catalogue of shark species known to date. Vol. 2. Bullhead, mackerel and carpet sharks (Heterodontiformes, Lamniformes and Orectolobiformes). FAO Species Catalogue for Fishery Purposes no. 1. FAO: Rome, Italy: 2001;2:1-269.

Compagno LJV, Dando M, Fowler S. Sharks of the world. New Jersey: Princeton University Press; 2005.

Ebert DA, Stehmann MFW. FAO Species Catalogue for Fishery Purposes No. 7. Sharks, Batoids and Chimaeras of the North Atlantic. Rome: Food and Agriculture Organization of the United Nations; 2013.

Ebert DA, Fowler S, Compagno L. Sharks of the world: a fully illustrated guide. Plymouth: Wild Nature Press; 2013. 
Hacohen-Domené A, Polanco-Vásquez F, Graham RT. First report of the whitesaddled catshark Scyliorhinus hesperius (Springer 1966) in Guatemala's Caribbean Sea. Mar Biodivers Rec. 2016;9(1):101.

Kyne PM, Carlson JK, Ebert DA, Fordham SV, Bizzarro JJ, Graham RT, Kulka DW, Tewes EE, Harrison LR, Dulvy NK. The conservation status of North American, Central American, and Caribbean Chondrichthyans, Technical report. Vancouver: IUCN Species Survival Commission Shark Specialist Group; 2012.

McLaughlin DM, Morrissey JF. New records of elasmobranchs from the Cayman Trench. Jamaica Bull Mar Sci. 2004;75:481-5.

Paul L, Fowler S. (SSG Australia \& Oceania Regional Workshop, March 2003), Heptranchias perlo. The IUCN Red List of Threatened Species 2003: e. T41823A10572878. http://dx.doi.org/10.2305/IUCN.UK.2003.RLTS. T41823A10572878.en. Accessed 5 Jan 2017.

Polanco-Vásquez F, Hacohen-Domené A, López T, Pacay A, Graham RT. First record of the chimaera Neoharriota carri (Bullis and Carpenter 1966) in the Caribbean of Guatemala. Mar Biodivers Rec. 2017;10:1.

Tanaka S, Mizue K. Studies on sharks. 11. Reproduction in female Heptranchias perlo. Bull Fac Fish Nagasaki Univ. 1977;42:1-9.

Thorson TB, Cowan CM, Watson DE. Sharks and sawfish in the lake Izabal-Rio Dulce system. Guatemala Copeia. 1966;3:620-2.

Submit your next manuscript to BioMed Central and we will help you at every step:

- We accept pre-submission inquiries

- Our selector tool helps you to find the most relevant journal

- We provide round the clock customer support

- Convenient online submission

- Thorough peer review

- Inclusion in PubMed and all major indexing services

- Maximum visibility for your research

Submit your manuscript at www.biomedcentral.com/submit
Biomed Central 